DOI: $10.26693 / \mathrm{jmbs} 06.05 .356$

UDC 616.28-008.5-085.851.8-057.875-054.6

Kyrychenko M. P., Shenger S. V., Goncharova A. V., Dunaeva O. V.

\title{
On the Issue of Functional Vestibular Disorders and Methods of Their Correction in Foreign Students
}

\author{
Kharkiv National Medical University, Ukraine
}

\begin{abstract}
Vestibular stimulations influence the somaticvegetative functions of the organism, including the muscular system. The prevalence of a sedentary lifestyle among students and, especially foreign students, in combination with a prolonged fixed position of the head, promotes to the development of functional-vestibular disorders. This affects both the academic progress and health state of these students.

The purpose of the work was to study the influence of vestibular disorders of the motor and visual analyzers, with the following correction of these disorders by using relax gymnastics with yoga elements.

Materials and methods. The study was carried out during 4 months, and included 52 students from India, studying at the $2^{\text {nd }}$ year of Kharkiv National Medical University. A block of anamnestic and diagnostic-instrumental research methods was used.
\end{abstract}

Results and discussion. As a result of the observations, it was found that the initial level of body physical development and the degree of an adequacy of the mode of mental work and rest to the nature of the educational process play a large role in the degree of occurrence of vestibular reactions. Particular attention was paid to the assessment of vestibular stability, which was reduced in 21 out of 52 students, which was noted on the basis of the presence of 2 or more parameters defined during the study. These students were included in the experimental group (12 people) and the control group (9 people). All these students had either a reduced level of physical development or various deviations in the level of body physical development. For the students of experimental group three-months cycle of relax-training gymnastics with yoga elements was proposed. For all students, vestibular irritations reduced the accuracy of the performed movements, but for students with a reduced level of physical development, these indicators were worse and more stable. As a result, the students of the experimental group demonstrated positive dynamics of the correction for vestibular adaptation to the studying process in comparison with the students of the control group that did not demonstrate the same results.

Conclusion. The results of the investigation which was carried out allow to formulate the following conclusions: 1) Vestibular reactions depend on the initial level of physical development of students and the nature of the educational process; 2) Regular stimulations of the vestibular apparatus on the background of relaxation and training exercises with yoga elements contribute to an increase in the motor functions of the body; 3) Vestibular irritations cause more frequent and expressed somatic reactions in comparison with vegetative ones.

Keywords: analyzers, foreign students, vestibular disorders, corrective gymnastics, yoga.

Research relation to the programs, plans, and department themes. The work is a fragment of research «Autonomic regulation in students in the process of adaptation to social, temporal and natural factors», the number of state registration is $0118 \cup 000947$.

Introduction. The functional interdependence of physiological processes in the system of analyzers is constantly formed and develops depending on the physical activity of a person in the specific conditions of his state [1-4].

Particular interest is the nature of vestibular changes against the background of properly performed muscle work. Vestibular irritations affect the somatic-vegetative functions of the body, including the muscular system. Disturbances of the correct periodicity of static and dynamic loads can negatively affect the functioning of the vestibular apparatus [5].

The prevalence of a sedentary lifestyle adversely affects all body functions. This is especially true for students. Long time being in a sitting position damage the motor system and causes the development of chronic muscle overstraining $[6,7]$.

Another problem is connected with the wrong position of the head. The head tilted forward (reading, writing, typing) causes not only functional changes in the locomotor system, but also in the vestibular apparatus. Being relatively heavy (it weighs from 4.5 to $6.5 \mathrm{~kg}$ ), the head is not located directly above the shoulders during long fixed position. The center of gravity of the human body is displaced and, therefore the correct balance is disturbed. Taking into consideration that a modern student is in a sitting position on average 10-12 hours it can be assumed that this situation adversely affects the work of the vestibular apparatus.

In the young people living a moment lifestyle and those who alternate the static overstraining with the dynamic muscle loading, such phenomena, as a rule, are not observed. 
Foreign students represent a completely different category of students. Being very far from home, in unusual conditions for themselves (social, domestic, etc.), they cannot, and often do not want to pay attention to functional disorders associated with chronic muscle overstraining. Inactive, without initiative, spending most of the time in different passive states, having poor posture, weak musculature, reduced chest sizes, having a wide range of body weight from overweight to underweight, they are forced to participate in studying process trying to fulfill all demands of the curriculum, forming at the same time pre-pathological, and then pathological conditions [8].

The purpose of the work was to study the vestibular stimuli influence on the functional state of the motor and visual analyzers and correction of the revealed disorders by the method of relaxation gymnastics with yoga elements.

Materials and methods of research. During the 4-month observation, 52 students (3 groups) from India were examined. In the conditions of the Department of Physiology of Kharkiv National Medical University the students' anamnestic data were collected and their level of physical development was determined using anthropometric data and fulfilling functional tests. All these students studied at the $2^{\text {nd }}$ course and their age was in the range from 19 years old to 22 years old. Living conditions were satisfactory, the nature of the food and feeding regimen was irregular, night sleep was less than 8 hours, sedentary work took on average 10-12 hours. In anamnesis the chronic diseases were absent. $62 \%$ of the investigated students demonstrated decreasing of physical development level, including various disorders of posture, the predominance of a conical and flattened form of the chest, decreasing of respiratory excursion of the lungs, decreased vital lung capacity and functional respiratory tests (breath holding after inhalation and exhalation). 17 students had local variations of deformation of the spinal column. In addition, auscultation of the lungs and heart was carried out. Blood pressure and pulse properties were determined at the state of rest and during and after physical loading (physical exercises). Twice a day body temperature was measured. No gross deviations from the average norm were noted. The investigated students were consulted by a general practitioner.

The state of the vestibular analyzer was tested on the basis of autonomic and somatic reactions that occur when rotating on a Barany chair with head down at a speed of 1 revolution for 2 seconds. The participants of the study underwent 3 times examination: at rest before rotation, immediately after rotation and 3 minutes after stopping rotation. During the study the indexes of the cardiovascular system on the basis of blood pressure and pulse were investigated.
We evaluated vestibular stability in our conditions according to:

1. Subjective indicators (absence of complaints, dizziness, nausea, tinnitus aurium, sensation of heat, lack of air);

2. Imbalance (stability in the Romberg position, finger-nasal test),

3. Gait disturbance along in a straight line;

4. Violation of handwriting. The field of vision was determined by the outer, inner, upper and lower meridians using the Foster perimeter.

All experiments were conducted in accordance with the Council of Europe Convention "On the Protection of Human Rights and Dignity of the Human Being with regard to the Application of Biology and Medicine Application of Biological and Medicine Achievements (ETS No. 164)" dated 04.04.1997, and the Helsinki Declaration of the World Medical Association (2008).

Results. As a result of the observations, it was found that the initial level of body physical development and the degree of an adequacy of the mode of mental work and rest to the nature of the educational process play a large role in the degree of occurrence of vestibular reactions.

The estimation of vestibular stability showed that 21 from 52 students had a decrease (deterioration) of the stability of the vestibular apparatus, noted on the basis of the presence of 2 or more defined parameters. All these students had either a reduced level of physical development or various deviations in the level of body physical development. For all students, vestibular irritations reduced the accuracy of the performed movements, but for students with a reduced level of physical development, these indicators were worse and more stable.

After rotation in the investigated contingent there were no significant changes. Based on the study, a group of 19 people (11 males and 8 females) with reduced (functionally insufficient) vestibular resistance was determined. They were offered the 3-month cycle of corrective relaxation-training gymnastics with elements of yoga [9]. The gymnastics was held 2 times a day (in the morning before classes and in the evening after classes) lasting 20-25 minutes with obligatory exercises (asanas) for the head and neck.

The main emphasis was placed on such asanas as:

1. Rotational head movements in a standing position.

2. The balancing on the right (left) leg. Asana "Ballerina".

3. The pose of the triangle in a standing position.

4. Asana "The rack over" - the full tilt of the body forward 
5. Asana "The Dog"

6. Asana "The Camel"

7. Asana "The Cat"

8. Asana "The Pigeon" and "The Pigeon drinking water"

9. Balance with arms and legs

10. Asana "The Screw"

11. Purna sarpasana

12. Asana "The Bow"

13. Asana "The Swan"

14. Asana "The Plow"

15. Asana "The Wheel"

The choice of asanas was carried out with taking into consideration the level of body physical development of students, individually. It was recommended that the first week (preparatory) was carried out with a limited number of asanas, with slow tempo, incomplete range of motion in the joints, low intensity, prolonged relaxation between asanas, the minimum dosage (number of repetitions). With good tolerance of the students doing this additional (special) physical activity, which was integrated into their daily lives, the exercises became more complicated. All these exercises were recommended to fulfill without feeling any discomfort.

Students drew attention to such details as entering into the asana, being in it and going out of it. All students were instructed on the mode, conditions and technique of the exercises. 7 students refused this correction. They composed the control group (6 males and 1 female). The remaining 12 students (6 males and 6 females) composed the experimental group. After 3 months, these two groups went through the investigation phase again with all the elements of the examination. The received results showed that 8 students $(66.7 \%)$ demonstrated significant improvement in vestibular stability. At the same time, they also noted a tendency to improvement of general physical indicators of their individual development. 4 students $(33.3 \%)-3$ males and one female did not give positive dynamics of their states. We explained it as not observing the general movement regime during the day and focusing their correction only on the technique of performing exercises. It was clearly insufficient during many hours of mental loading and work. After 4 weeks, an additional examination of the students of both groups was conducted. The complete and stable relief of vestibular incompetence was observed already in 11 students (92.1\%). One student, had the decreasing of the negative effects significantly, but yet they were noted in a mild form. When interviewing the students of the experimental group, the positive dynamics of their integration into the educational process was established. It was reflected in the quality of students' studying at the university.

The students of the control group did not give positive dynamics of vestibular adaptation to the edu- cational to the educational process during the examination. Their functional incompetence of the vestibular apparatus remained the same. The irritation of the vestibular apparatus in all the students of the experimental group showed a decreasing of blood pressure reactions. In the students of the control group, the systolic pressure fluctuation range compared to the initial data was $2.31+-0.21 \mathrm{~mm} \mathrm{Hg}$. Diastolic pressure did not change significantly. Heart rate did not demonstrate the reliable patterns of the reactions to vestibular irritations, with the exception of female students in the control group where there was an increase of heart rate by $4.98+-0.21$ beats per 1 minute.

Discussion. Various functional disorders of students' health state suggest an active search for different methods of prevention and correction of these disorders $[10,11]$. In the pathogenesis of these conditions, psycho-vegetative influences are clearly traced. They negatively affect the locomotor functions, and through them the adaptive capabilities of various analyzers, including the vestibular one. During the educational process (classroom and at home), an increase of the contribution of the sympathetic nervous system to the general spectrum of the neuro-humoral reaction often leads to an imbalance of various departments of the higher nervous system in comparison with the initial (pre-educational) level. In this regard the individual harmonizing methods for correcting such disturbances should be used and this fact predetermined our choice [10].

Skeletal muscles are able, with appropriate activation, to show considerable strength and power for a rather long time. However, with repetitive monotonous reproduction of the same muscle tension, a progressively developing decrease of working capacity inevitably arises, including mental work. In its simplest form, it is defined as neuromuscular fatigue.

In order to partially compensate for such a condition and the possible extension of performing work (especially sedentary), the entire system of analyzers, including the vestibular one, is stressed. But since the work is long, lasting for many hours, at some stage without organic damage, dysfunctional phenomena occur which when sitting at work are unspectacular and asymptomatic. But they can accumulate and intensify. To a certain extent, the temporal parameters of muscle contraction and muscle relaxation also can contribute to this. The individual differences of these phenomena are certainly obvious: the initial level of physical development, gender, age, health status, body composition, the role of genetic factors, as well as weather, climate and geographical conditions. Nowadays, the search for an averaged low-cost and economically profitable way to normalize the somatic-vegetative functions of students is still actual.

\section{Conclusion}

1. The range of vestibular reactions depends on the initial level of physical development and 
the degree of adequacy of regimen for mental work and rest to the nature of the educational process.

2. Regular irritations of the vestibular apparatus on the background of a systematic relaxation-training gymnastics with elements of yoga contribute to an increase in the motor functions of the body in students with a static motor stereotype.
3. Vestibular irritations cause more frequent and expressed somatic reactions in comparison with vegetative ones.

Perspectives for further research. As an alternative to this phenomenon, especially among foreign students, a controlled cycle of correction and prevention of functional disorders of the vestibular apparatus in the form of relaxation-training gymnastics with elements of hatha yoga could be performed.

\section{References}

1. Boldyn AV, Agasarov LG, Tardov MV, Kunelskaya NL. Rol dysfunktsyy vysochno-nyzhnechelyustnogo sustava y okklyuzyonnykh narushenyy $v$ patogeneze somatogennogo kokhleovestybulyarnogo syndroma [The role of dysfunction of the temporomandibular joint and occlusal disorders in the pathogenesis of somatogenic cochleovobular syndrome]. Almanakh klynycheskoy medytsyny. 2016 Oct; 44(7): 798-808. [Russian]. doi: 10.18786/2072-0505-2016-44-7-798-808

2. Patel VR, Zee DS. The cerebellum in eye movement control: nystagmus, coordinate frames and disconjugacy. Eye (Lond). 2015; 29(2): 191- 5. PMID: 25397778. PMCID: PMC4330284. doi: 10.1038/eye.2014.271

3. Kheradmand A, Zee DS. Cerebellum and ocular motor control. Front Neurol. 2011 2(53):1-15. PMID: 21909334. PMCID: PMC3164106. doi: 10.3389/fneur.2011.00053

4. De Nunzio AM, Nardone A, Schieppati M. Head stabilization on a continuously oscillating platform: the effect of a proprioceptive disturbance on the balancing strategy. Exp Brain Res. 2005; 165(2): 261-272. PMID: 15856203. doi: 10.1007/s00221-005-2297-7

5. Sharov BB. Vestybulyarnyy rezonans $v$ statokynetycheskoy funktsyonalnoy systeme [Vestibular resonance in the static functional system]. Vestnyk Yuzhno-Uralskogo gosudarstvennogo unyversyteta: obrazovanye, zdravookhranenye, fyzycheskaya kultura. 20072 (74):8 8-90. [Russian]. doi: 10.5771/0040-117X-2007-1-88

6. Thyfault JP, Du M, Kraus WE, Levine JA, Booth FW. Physiology of sedentary behavior and its relationship to health outcomes. Med Sci Sport Exerc. 2015; 47(6): 1301-1305. PMID: 25222820. PMCID: PMC4362885. doi: 10.1249/MSS.0000000000000518

7. Park JH, Moon JH, Kim HJ, Kong MH, Oh YH. Sedentary Lifestyle: Overview of Updated Evidence of Potential Health Risks. Korean J Family Med. 2020; 41(6): 365-373. PMID: 33242381. PMCID: PMC7700832. doi: $10.4082 / \mathrm{kffm} .20 .0165$

8. Booth FW, Roberts CK, Thyfault JP, Ruegsegger GN, Toedebusch RG. Role of Inactivity in Chronic Diseases: Evolutionary Insight and Pathophysiological Mechanisms. Physiolog Rev. 2017; 97(4): 1351-1402. PMID: 28814614. PMCID: PMC6347102. doi: 10.1152/physrev.00019.2016

9. Klassycheskaya yoga («Yoga-sutry» Patandzhaly y «Vyasa-bkhashya») [Classical yoga ("Yoga-Sutra" Patanjali and "Vyasa-Bhashya")]. Per s sanskryta, vved, komment i rekonstruktsyya systemy Ostrovskoy EP, Rudogo VY. M: Nauka; 1992. 264 s. [Russian]

10. Fishman LM, GroessI EJ, Sherman KJ. Serial case reporting yoga for idiopathic and degenerative scoliosis. Global Advanc Health Med. 2014; 3(5): 16-21. PMID: 25568820. PMCID: PMC4268609. doi: 10.7453/gahmj.2013.064

11. Eardley-Harris N, Munn Z, Cundy PJ, Gieroba TJ. The effectiveness of selective thoracic fusion for treating adolescent idiopathic scoliosis: a systematic review protocol. JBI Database System Rev Implementat Rep. 2015; 13(11): 4-16. PMID: 26657460. doi: 10.11124/jbisrir-2015-2338

УДК 616.28-008.5-085.851.8-057.875-054.6

\section{К ВОПРОСУ О ФУНКЦИОНАЛЬНО-ВЕСТИБУЛЯРНЫХ РАССТРОЙСТВАХ И МЕТОДЫ ИХ КОРРЕКЦИИ У ИНОСТРАННЫХ СТУДЕНТОВ \\ Кириченко М. П., Шенгер С. В., \\ Гончарова А. В., Дунаева О. В.}

Резюме. Вестибулярные раздражения влияют на соматовегетативные функции организма, включая мышечную систему. Превалирование сидячего образа жизни у учащейся молодежи и, особенно иностранных студентов, в комбинации с длительным фриксированным положением головы способствует развитию функционально-вестибулярных расстройств. Это сказывается, как на успеваемости этих студентов, так и на здоровье.

Целью настоящего исследования являлось изучение влияния вестибулярных расстройств двигательного и зрительного анализаторов, с последующей коррекцией этих нарушений методом релаксационной гимнастики с элементами йоги. 
Объект и методы. Исследование проводилось в течение 4-х месяцев, в которое было включено 52 студента из Индии, обучающихся на 2 курсе ХНМУ. Использован блок анамнестических и диагностически-инструментальных методов исследования.

Результаты. Особое внимание уделялось оценке вестибулярной устойчивости, которое у 21 студента была снижена. Эти студенты вошли в экспериментальную группу (12 человек) и контрольную группу (9 человек). Экспериментальной группе был предложен трёхмесячный цикл коррегирующей релаксационно-тренирующей гимнастики с элементами йоги. Как результат, студенты экспериментальной группы продемонстрировали позитивную динамику коррекции вестибулярной адаптации к учебному процессу, чего не отмечалось у студентов контрольной группы.

Выводы. Результаты исследования позволили сделать следующие выводы: Вестибулярные реакции зависимы от исходного уровня фризического развития и характера учебного процесса. Регулярные раздражения вестибулярного аппарата на фоне проводимой релаксационно-тренирующей гимнастики с элементами йоги способствуют повышению моторных функций организма. Вестибулярные раздражения вызывают более частые и выраженные соматические реакции по сравнению с вегетативными.

Ключевые слова: анализаторы, иностранные студенты, вестибулярные расстройства, коррегирующая гимнастика, йога.

УДК 616.28-008.5-085.851.8-057.875-054.6

ДО ПИТАННЯ ПРО ФУНКЦІОНАЛЬНО-ВЕСТИБУЛЯРНІ РОЗЛАДИ

ТА МЕТОДИ ЇХ КОРЕКЦІЇ У ІНОЗЕМНИХ СТУДЕНТІВ

Кириченко М. П., Шенгер С. В.,

Гончарова А. В., Дунаєва О. В.

Резюме. Вестибулярні подразнення впливають на сомато-вегетативні фрункції організму, включаючи м'язову систему. Превалювання сидячого способу життя в учнівської молоді та, особливо у іноземних студентів, в комбінації з тривалим фріксованим положенням голови сприяє розвитку функціонально- вестибулярних розладів. Це позначається, як на успішності цих студентів, так і на стані їх здоров'я.

Метою цього дослідження було вивчення впливу вестибулярних розладів рухового і зорового аналізаторів, з подальшим коригуванням цих порушень методом релаксаційної гімнастики з елементами йоги.

Об'єкт та методи. Дослідження проводилося протягом 4-х місяців, в яке було включено 52 студента 3 Індії, які навчаються на 2 курсі ХНМУ. Був використаний блок анамнестичних та діагностичноінструментальних методів дослідження. Особлива увага приділялася оцінці вестибулярної стійкості, яке у 21 студента була знижена. Ці студенти увійшли в експериментальну групу (12 осіб) і контрольну групу (9 осіб). Експериментальній групі був запропонований тримісячний цикл корегуючої релаксаційно-тренуючої гімнастики з елементами йоги.

Результати. Як результат, студенти експериментальної групи продемонстрували позитивну динаміку корекції вестибулярної адаптації до навчального процесу, чого не відзначалося у студентів контрольної групи.

Висновки. Результати дослідження дозволили зробити наступні висновки: Вестибулярні реакції залежні від вихідного рівня фрізичного розвитку та характеру навчального процесу. Регулярні подразнення вестибулярного апарату на тлі проведеної релаксаційно-тренуючої гімнастики з елементами йоги сприяють підвищенню моторних функцій організму. Вестибулярні подразнення викликають частіші і виражені соматичні реакції в порівнянні з вегетативними.

Ключові слова: аналізатори, іноземні студенти, вестибулярні розлади, корегуюча гімнастика, йога.

ORCID and contributionship:

Michael P. Kyrychenko : 0000-0002-5329-751X A, B, C, F

Svetlana V. Shenger : 0000-0001-5382-2225 B, C, D, F

Alina V. Goncharova : 0000-0002-8817-2610 B, C, E, F

Olga V. Dunaeva : 0000-0002-1057-4046 B, C, E, F

A - Work concept and design, B - Data collection and analysis,

C - Responsibility for statistical analysis, D - Writing the article,

E - Critical review, F - Final approval of the article 


\section{CORRESPONDING AUTHOR}

\section{Olga V. Dunaeva}

Kharkiv National Medical University,

Medical Faculty 5, Physiology Department

4, Nauky Avenue, Kharkiv 61022, Ukraine,

tel: +380675719309, e-mail: ov.dunaieva1@knmu.edu.ua

The authors of this study confirm that the research and publication of the results were not associated with any conflicts regarding commercial or financial relations, relations with organizations and/or individuals who may have been related to the study, and interrelations of coauthors of the article.

Стаття надійшла 02.09.2021 p. Рекомендована до друку на засіданні редакційної колеаії після рецензування 